\title{
Pregnancy-associated changes in the endocrine pancreas of normoglycaemic streptozotocin-treated Wistar rats
}

\author{
B.Ziegler, S. Lucke, W. Besch and H.-J.Hahn \\ Central Institute of Diabetes Gerhardt Katsch, Karlsburg, GDR
}

\begin{abstract}
Summary. The effect of pregnancy on pancreatic insulin content and relative B-cell volume has been studied in normoglycaemic Wistar rats treated with streptozotocin 14 days before mating. A single intravenous injection of streptozotocin ( $30 \mathrm{mg} / \mathrm{kg}$ body weight) caused a significant reduction of pancreatic insulin content and B-cell volume. The islet insulin content was $60 \%$ of control values. However, pregnancy-associated adaptation was preserved in these streptozotocin-treated animals. Plasma insulin levels, pancreatic insulin and Bcell volume were significantly enhanced compared with non-pregnant rats investigated on the same date. The incorporation of $\left[{ }^{3} \mathrm{H}\right]$-thymidine into islets from pregnant rats (day
\end{abstract}

10.5) was higher than that in islets isolated from non-pregnant animals. After delivery insulin content and B-cell volume returned to pre-pregnant values. Also during a longer period after streptozotocin treatment (156 days), no measurable enhancement of B-cell volume and pancreatic insulin content was observed indicating the unresponsiveness of residual B cells to compensate spontaneously for the loss despite persisting normoglycaemia.

Key words: Pregnancy, B-cell volume, insulin, Wistar rats, streptozotocin administration, islets, DNA synthesis.
The normal endocrine pancreas responds to the metabolic changes of pregnancy with an enhancement of pancreatic B-cell volume and an increase of insulin synthesis and release [1-5]. Furthermore, it is well known that a pre-existing disturbance of the carbohydrate metabolism is generally aggravated by pregnancy [6]. Therefore, treatment with a sub-diabetogenic dose of streptozotocin (STZ) could be a suitable means for establishing whether residual B-cell volume is sufficient to maintain normoglycaemia during pregnancy. Moreover, it should be possible to examine whether the residual B-cells are able to respond to pregnancy with increased reactivity, measured as an enhancement of B-cell volume, DNA synthesis in islets, peripheral and pancreatic insulin concentration, and whether these changes return to pre-pregnant values as observed in normal rats $[1,7]$. In addition, we also investigated whether residual B cells, after moderate reduction, are able to compensate spontaneously for the loss under normoglycaemic conditions.

\section{Materials and methods}

\section{Animals}

Ten 12-week-old female Wistar rats (weight $\sim 170 \mathrm{~g}$ ) were fed ad libitum with commercial pelleted chow containing $62 \%$ carbohydrate,
$4 \%$ lipid and $20 \%$ protein, and injected either with vehicle or a single sub-diabetogenic dose of STZ $(30 \mathrm{mg} / \mathrm{kg}$ body weight, kindly supplied by Dr. J.E. Dulin, Upjohn, Kalamazoo, Ohio, USA). The STZ was dissolved in citrate buffer $(\mathrm{pH} 4.5)$ immediately before intravenous injection given at 08.00 hours. Only rats with a non-fasted plasma glucose value of $<9.45 \mathrm{mmol} / 1$ (within the $2 \mathrm{SD}$ range of agematched controls; $n=984$ ) without glycosuria were used. Test-tape strips (Biophan, VEB Laborchemie Apolda, Feinchemie Sebnitz, GDR) were used to check glycosuria. Animals with persisting normoglycaemia were either killed 14 days after STZ administration or mated (the day after mating was defined as day 0.5 of pregnancy). Ten or 19 days later pancreases from non-mated or pregnant rats were taken for insulin and B-cell volume estimation, or for islet isolation using collagenase digestion [8].

In a second set of experiments, STZ-treated rats were killed 60 days after delivery and were compared with STZ-treated rats without previous pregnancy. In addition, pancreatic insulin content and the relative B-cell volume were measured in a long-term study using animals 156 days after STZ administration. Intraperitoneal glucose tolerance tests ( $2 \mathrm{~g}$ glucose $/ \mathrm{kg}$ body weight) were carried out in fed animals 14 or 156 days after STZ administration.

At 08.00 hours blood samples were taken from a tail vein for analysis of plasma glucose using an auto-analyzer (Beckman Instruments, Fullerton, California, USA) and plasma insulin measured by radioimmunoassay against a rat insulin standard (Novo Industri, Copenhagen, Denmark) [9].

\section{Histological methods}

Pancreatic pieces were fixed in Bouin's solution, embedded in paraffin and cut into serial sections $7 \mu \mathrm{m}$ thick. For estimation of the relative islet and B-cell volume, 10 slices per pancreas were stained by 
Table 1. Effects of streptozotocin ( $30 \mathrm{mg} / \mathrm{kg}$ body weight) on plasma glucose, plasma insulin and the endocrine pancreas of Wistar rats

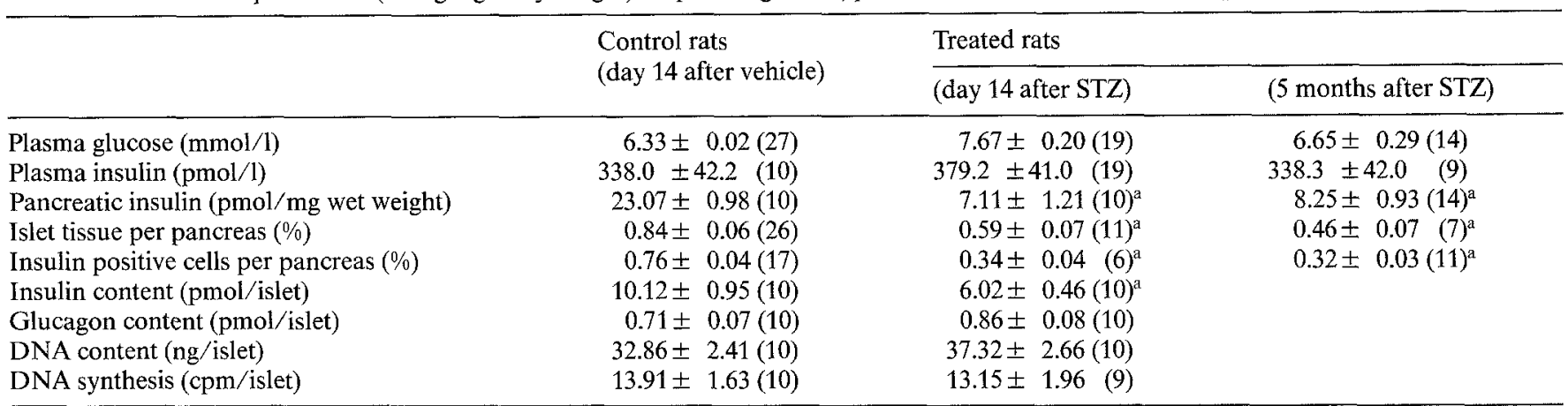

Values expressed as mean \pm SEM with number of observations in parentheses. ${ }^{a} p<0.01$ versus control rats

Table 2. Effects of pregnancy on body weight, plasma glucose and plasma insulin in Wistar rats treated with $30 \mathrm{mg} \mathrm{STZ} / \mathrm{kg}$ body weight 14 days before mating

\begin{tabular}{llll}
\hline Rats $(n=14)$ & $\begin{array}{l}\text { Body weight } \\
(\mathrm{g})\end{array}$ & $\begin{array}{l}\text { Plasma glucose } \\
(\mathrm{mmol} / \mathrm{l})\end{array}$ & $\begin{array}{l}\text { Plasma insulin } \\
(\mathrm{pmol} / \mathrm{l})\end{array}$ \\
\hline $\begin{array}{l}\text { Pre-pregnancy } \\
\quad(\text { day 0) }\end{array}$ & $202 \pm 4$ & $7.70 \pm 0.31$ & $417.4 \pm 41.8$ \\
$\begin{array}{l}\text { Early-pregnancy } \\
\quad(\text { day 7.5) }\end{array}$ & $212 \pm 4$ & $6.87 \pm 0.14$ & $425.5 \pm 46.6$ \\
$\begin{array}{l}\text { Mid-pregnancy } \\
\quad(\text { day 11.5) }\end{array}$ & $266 \pm 5^{\mathrm{a}}$ & $6.76 \pm 0.31$ & $696.6 \pm 50.2^{\mathrm{a}}$ \\
$\begin{array}{c}\text { Late-pregnancy } \\
\quad(\text { day 19.5) }\end{array}$ & $284 \pm 6^{\mathrm{a}, \mathrm{b}}$ & $5.89 \pm 0.23^{\mathrm{a}}$ & $650.7 \pm 68.9^{\mathrm{a}}$ \\
\hline
\end{tabular}

Values expressed as mean \pm SEM.

${ }^{\mathrm{a}} p<0.01$ versus pre-pregnant rats; ${ }^{\mathrm{b}}$ versus non-pregnant rats $(231 \pm 9 \mathrm{~g}(n=10)$ on the same date



Fig. 1. Mean plasma glucose levels during intraperitoneal administration of glucose $(2 \mathrm{~g} / \mathrm{kg}$ body weight $)$ in the fed state in the morning. A 14 days after vehicle, 14 days after STZ ( $30 \mathrm{mg} / \mathrm{kg}$ body weight), 5 months after STZ. Values represent mean \pm SEM measured in 30 control rats (body weight $180 \pm 5 \mathrm{~g}$ ) and 27 in each STZ-treated group (14 days after STZ: body weight $183 \pm 3 \mathrm{~g}$ ); (5 months after STZ: body weight $216 \pm 2 \mathrm{~g}) . \quad{ }^{+}(p<0.01)$ significantly enhanced plasma glucose values 10,30 and 60 min after glucose load compared with vehicle-treated control rats

haematoxylin-eosin or by indirect immunofluorescence for insulin (fluorescein-isothiocyanate labelled antiserum) [10]. The percentage of islet tissue and insulin-positive cells per pancreas was estimated by a point-counting method according to Weibel [11] using an ocular grid with 400 points (original distance between two points $25 \mu \mathrm{m}$ ). Four thousand points per slice were counted at a final magnification of $170-$ fold. The relative islet and B-cell volume is given as a percentage of the total pancreas [12].

\section{Determination of pancreatic insulin content}

The pancreatic insulin content was assayed after tissue disintegration (Ultra turrax, type TP-18-10, Janke \& Kunkel Staufen/Breisgau, FRG) in acid ethanol $\left(40 \mathrm{ml} \mathrm{H}_{3} \mathrm{PO}_{4} 1 \mathrm{~mol} / 1,380 \mathrm{ml}\right.$ ethanol $96 \%$, $20 \mathrm{ml}$ aqua bidest) using approximately $400 \mathrm{mg}$ pancreas $/ 12 \mathrm{ml}$ acid ethanol. Samples were stored at $8^{\circ} \mathrm{C}$ overnight, followed by ultrasonic disintegration. The supernatants of centrifuged extracts were stored at $-20^{\circ} \mathrm{C}$ until radioimmunoassay [9].

\section{Experiments with isolated islets}

Batches of 100 collagenase-isolated islets from fed female Wistar rats were taken on day 14 or 24 after vehicle or STZ application (nonpregnant or pregnant) and were incubated in glass Petri dishes $(6 \mathrm{~cm}$ diameter), with $2.5 \mathrm{ml} \mathrm{TCM} 199$ containing glucose $(10 \mathrm{mmol} / \mathrm{l})$ and supplemented with $10 \%$ fetal calf serum at $37^{\circ} \mathrm{C}$ in a humidified atmosphere [13].

The medium contained $2 \mathrm{mCi} / 1$ of (methyl- ${ }^{3} \mathrm{H}$ )-thymidine (sp. act. $26 \mathrm{Ci} / \mathrm{mmol}$, UVVR, Prague, Czechoslovakia) for a labelling period of $17 \mathrm{~h}$ at $37^{\circ} \mathrm{C}$. After removing the medium, batches of 40 sonicated islets were taken for measurement of DNA synthesis [13] and fluorometric assay of the DNA content [14]. Batches of five sonicated islets were used for radioimmunological insulin and glucagon determination $[9,15]$.

\section{Statistical analyses}

Results are presented as mean \pm SEM. Statistical significance was determined by the two tailed Student's t-test.

\section{Results}

\section{Measurements 14 days after STZ-treatment}

A single intravenous injection of STZ $(30 \mathrm{mg} / \mathrm{kg}$ body weight) caused a significant reduction of pancreatic insulin content, islet tissue and insulin-positive cells per pancreas (Table 1). The B-cell volume was approximately half and the insulin content $32 \%$ of values measured in control pancreases. Body weight and plasma insulin were similar to the control values (Table 1 ). The islet insulin content in STZ-treated rats was $60 \%$ of control values, whereas the glucagon content and DNA synthesis per islet were unchanged (Table 1). The STZtreated rats were normoglycaemic without glycosuria but their glucose tolerance was disturbed (Fig. 1). 


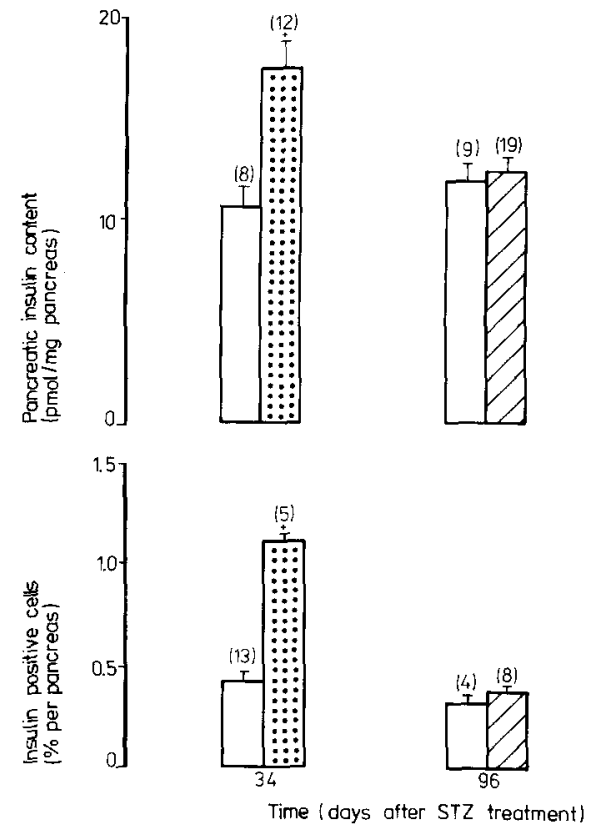

Fig. 2. Insulin content and percentage of insulin-positive cells in the pancreases of non-pregnant $(\square)$, pregnant (day 19.5; $:$. $)$ and post partum Wistar rats (r) treated with $30 \mathrm{mg} \mathrm{STZ} / \mathrm{kg}$ body weight on day 0 . Results are expressed as mean \pm SEM with the number of animals in parentheses. The pancreatic insulin content and B-cell volume were significantly enhanced by pregnancy $(p<0.01)$

\section{Pregnancy-associated alterations}

The body weight was higher at the end of pregnancy (day 19.5) than that of non-pregnant rats (Table 2). Plasma glucose levels were significantly lower during pregnancy, whereas plasma insulin levels increased in comparison to pre-pregnancy levels (Table 2). The pancreatic insulin content and B-cell volume were significantly enhanced on day 19.5 of pregnancy compared with non-pregnant STZ-treated animals investigated on the same date (Fig. 2). In non STZ-treated rats, the pancreatic insulin content increased from $19.7 \pm 2.34 \mathrm{pmol} / \mathrm{mg}$ wet weight $(n=12)$ to $38.4 \pm 3.90 \mathrm{pmol} / \mathrm{mg}$ wet weight $(n=12)$ during pregnancy (day 19.5).

Sixty days after delivery, both the pancreatic insulin content and B-cell volume corresponded to values from animals without previous pregnancy (Fig. 2).

The incorporation of $\left[{ }^{3} \mathrm{H}\right]$-thymidine into islets from pregnant rats (day 10.5) was significantly higher than that of islets isolated from non-pregnant animals $(20.00 \pm 3.10$ versus $12.26 \pm 1.12 \mathrm{cpm} /$ islet; $n=7$ in each group, $p<0.01$ ).

\section{Long-term observations}

The average body weight gain was $61 \pm 3.4 \mathrm{~g}$ during 5 months. Pancreatic insulin content and B-cell volume remained significantly diminished 5 months after STZ administration and did not differ from data obtained 14 days after STZ injection $(p<0.01)$. Plasma insulin and plasma glucose levels were similar to control values and to levels in STZ-injected rats on day 14 (Table 1). The impaired glucose tolerance persisted over this period (Fig. 1).

\section{Discussion}

A moderate dose of STZ reduced the pancreatic insulin content more markedly than either the islet or B-cell volume, indicating not only destruction of B cells but also a partial degranulation of remaining ones. This indication is supported by data obtained from isolated islets, which contain only $60 \%$ insulin but unchanged glucagon values compared with islets of control rats with a corresponding DNA content. Nevertheless, the residual $B$ cells are sensitive to glucose and can adequately maintain normal glucose homeostasis without glycosuria. Only such a loss of B cells which results in a metabolic decompensation seems to lead to a selective deterioration of glucose-induced insulin release [16,17]. Furthermore, B-cell replication was diminished by the permanent hyperglycaemia developed [18, 19]. Despite persisting normoglycaemia STZ-treated rats showed an impaired glucose tolerance and no measurable augmentation of B-cell volume over a period of 5 months. Therefore we conclude that normoglycaemia and impaired carbohydrate tolerance did not trigger the residual B cells to compensate for the B-cell loss. Probably the critical limit of B-cell destruction which would induce a pronounced renewal was not reached. Such regeneration perhaps occurs only in combination with an enhanced insulin requirement and/or transient hyperglycaemia [19]. Thus, we tried to achieve a pronounced B-cell growth by a physiological stimulus, namely pregnancy. It is well known that pregnancy increases insulin demand and B-cell growth with corresponding enhancement of B-cell volume, insulin biosynthesis and release [1-6]. Our STZ-treated normoglycaemic rats are responsive to pregnancy as shown by a decrease of plasma glucose and an increase of peripheral and pancreatic insulin concentrations. The doubling of B-cell volume and islet DNA synthesis corresponded to data obtained in normal pregnant rats $[2,13,20]$ but not in diabetic pregnant rats [21]. In normoglycaemic STZtreated Wistar rats van Assche et al. [21] also failed to demonstrate a pregnancy-associated increase in B-cell volume. The only difference between the latter investigation and this study was the time of mating after STZ injection. Van Assche et al. [21] injected STZ ( $30 \mathrm{mg} / \mathrm{kg}$ body weight) on the day of mating, whereas our rats were mated 14 days after STZ treatment to prevent an interaction of the response to the early injury of islets by STZ [22] and pregnancy-associated effects. However, pregnancy failed to induce a permanent enhancement of a reduced B-cell volume: B-cell volume and pancreatic insulin content returned to pre-pregnant values after delivery as described in normal pregnant rats $[1,7]$. 
From our results we can conclude that these STZtreated animals are responsive to the hormonal and biochemical changes of pregnancy and its termination. The lack of spontaneous compensation for a moderate Bcell loss, despite well preserved responsiveness to a Bcell growth promoting state, provides further evidence for a limition of B-cell renewal in adult rodents even if normoglycaemia is maintained.

Acknowledgements. This study is part of the research project HFR 22 of the Ministry of Health of the German Democratic Republic. We are grateful to Ch. Kauert, G.Strauch, E. Radloff, and M. Henkel for technical assistance, to E. Heiden for typing the manuscript and to J. Fanning for language editing.

\section{References}

1. Hellman B (1960) The islets of Langerhans in the rat during pregnancy and lactation with special reference to the changes in the B/A cell ratio. Acta Obstet Gynecol Scand 39: 331-342

2. Van Assche FA (1974) Quantitative morphologic and histoenzymatic study of the endocrine pancreas in non-pregnant and pregnant rats. Am J Obstet Gynecol 118: 39-41

3. Bone AJ, Taylor KW (1976) Metabolic adaptation to pregnancy shown by increased biosynthesis of insulin in islets of Langerhans isolated from pregnant rats. Nature 262: 501-502

4. Green JC, Taylor KW (1972) Effects of pregnancy in the rat on the size and insulin secretory response of the islets of Langerhans. $J$ Endocrinol 54: 317-325

5. Ziegler B, Ziegler M, Fiedler H (1978) Effects of pregnancy on the glucose-induced insulin release from cultivated pancreatic islets of the rat. Experienta 34: 138-139

6. Yen SSC, Rsai CC, Vela P (1971) Gestational diabetogenesis quantitative analyses of the glucose-insulin relationship between normal pregnancy and pregnancy with gestational diabetes. Am J Obstet Gynecol 6: 792-800

7. Marynissen G, Aerts L, Van Assche FA (1983) The endocrine pancreas during pregnancy and lactation in the rat. J Dev Physiol 5: 373-381

8. Hahn HJ (1978) Die isolierte Langerhans'sche Insel, ein Modell zur Untersuchung der Insulinsekretion in vitro. Endokrìnologie 71: 308-324

9. Gottschling D, Ziegler M, Wilke W, Michael R (1974) Radioimmunoassay von Plasmainsulin. Methodenkritische Untersuchungen. Radiobiol Radiother 15:91-97
10. Lacy PE, Davies J (1959) Demonstration of insulin in mammalian pancreas by the fluorescent antibody method. Stain Technol 34: $85-90$

11. Weibel ER (1969) Stereological principles for morphometry in electron microscopic cytology. Int Rev Cytol 26: 235-302

12. Lucke S, Ziegler B, Weidlich K, Barowski U, Besch W, Hahn HJ (1985) The effect of subdiabetogenic streptozotocin doses on rat beta cell volume and functions. Biomed Biochim Acta 44: 167-171

13. Ziegler B, Kohnert KD, Noack S, Hahn HJ (1982) Effects of 3-isobutyl-1-methylxanthine on secretory response, cAMP accumulation and DNA synthesis of islets from postnatal and adult Wistar rats. Acta Biol Med Germ 41: 1171-1177

14. Hinegardner RT (1971) An improved fluorometric assay for DNA. Anal Biochem 39: 197-201

15. Ziegler M, Michael R, Stein HH, Klatt D (1974) Radioimmunoassay von Pankreasglukagon isolierter Langerhans'scher Ratteninseln nach dem Prinzip der Rücktitration. Radiobiol Radiother 15: 79-84

16. Weir GC, Clore ET, Zmachinski CJ, Bonner-Weir S (1981) Islet secretion in a new experimental model for non-insulin-dependent diabetes. Diabetes 30: 590-595

17. Bonner-Weir S, Trent DF, Weir GC (1983) Partial pancreatectomy in the rat and subsequent defect in glucose-induced insulin release. J Clin Invest 71: 1544-1552

18. Logothetopoulos J, Brodsky G, Kern MF (1970) Islet cell proliferation in experimental and genetic diabetes. In: Falkmer S, Hellman B, Täljedal I-B (eds) The structure and metabolism of the pancreatic islets. Pergamon Press, Oxford, pp 15-23

19. Hellerström $\mathrm{C}$ (1984) The life story of the pancreatic $\beta$ cell. Diabetologia 26: 393-400

20. Green JC, Seifi SE, Perrin D, Howell SL (1981) Cell replication in the islets of Langerhans of adult rats: effects of pregnancy, ovariectomy and treatment with steroid hormones. J Endocrinol 88: $219-224$

21. Van Assche FA, Aerts L, Gepts W (1979) Morphological changes in the endocrine pancreas in pregnant rats with experimental diabetes. J Endocrinol 80: 175-179

22. Brodsky G, Logothetopoulos J (1969) Streptozotocin diabetes in the mouse and guinea pig. Diabetes 18: 606-611

Received: 11 June 1984

and in revised form: 26 November 1984

Dr. B.Ziegler

Central Institute of Diabetes "Gerhardt Katsch"

DDR-2201 Karlsburg

GDR 